Meta

Journal des traducteurs

Translators' Journal

\title{
Simultaneous Interpretation with "Training Wheels"
}

\section{Karla Déjean Le Féal}

Volume 42, numéro 4, décembre 1997

URI : https://id.erudit.org/iderudit/003453ar

DOI : https://doi.org/10.7202/003453ar

Aller au sommaire du numéro

Éditeur(s)

Les Presses de l'Université de Montréal

ISSN

0026-0452 (imprimé)

1492-1421 (numérique)

Découvrir la revue

Citer cet article

Déjean Le Féal, K. (1997). Simultaneous Interpretation with "Training Wheels". Meta, 42(4), 616-621. https://doi.org/10.7202/003453ar

\section{Résumé de l'article}

L'article porte sur l'approche pédagogique de l'interprétation simultanée. Après un survol critique des exercices couramment pratiqués pour initier les étudiants à cette technique complexe, il traite plus longuement du rôle que l'interprétation consécutive peut jouer en tant que moyen didactique dans l'enseignement de la simultanée. Les objectifs à atteindre et la procédure à suivre sont exposés en détail tout comme les avantages de cette démarche et les résultats obtenus. 


\title{
SIMULTANEOUS INTERPRETATION WITH "TRAINING WHEELS"
}

\author{
KARLA DÉJEAN LE FÉAL \\ Université Paris III-Sorbonne Nouvelle (ESIT), Paris, France
}

\begin{abstract}
Résumé
L'article porte sur l'approche pédagogique de l'interprétation simultanée. Après un survol critique des exercices couramment pratiqués pour initier les étudiants à cette technique complexe, il traite plus longuement du rôle que l'interprétation consécutive peut jouer en tant que moyen didactique dans l'enseignement de la simultanée. Les objectifs à atteindre et la procédure à suivre sont exposés en détail tout comme les avantages de cette démarche et les résultats obtenus.
\end{abstract}

\begin{abstract}
This article deals with the teaching of simultaneous interpretation. It briefly reviews the procedures most commonly employed at the start of training in simultaneous and goes on to describe one particular approach: the use of consecutive interpretation to facilitate training in simultaneous. The rationale for and objectives of this approach as well as its practical application, advantages and results are discussed.
\end{abstract}

\section{INTRODUCTION}

Teaching simultaneous interpretation (SI) requires special attention for a number of reasons. First, in SI there is much less scope than there is in consecutive interpreting (CI) for breaking down the learning process into smaller, more manageable tasks. Thus, SI seems daunting to most students and if their first attempt in the booth is unsuccessful, they are often skittish and apprehensive about persevering.

Secondly, in teaching CI it is possible to lead students step by step through the underlying mental process, but this is not possible in SI. Hence other means must be sought to make sure that they do not go off at a tangent, but get the entire process right from the start.

Furthermore, while in consecutive the time lag between perception and re-expression of the message shields students from the risk of mindless parroting, in simultaneous they are directly exposed to this temptation and may easily succumb to it without even being aware of it. Indeed, whereas in CI students cannot fail to perceive methodological errors, because these errors lead to problems of retention or re-expression, in SI it is easy for them to slip into transcoding rather than interpreting, because they subjectively perceive far less difficulty in re-expression. Consequently they are at risk of acquiring bad habits when practicing on their own between classes.

The risk is compounded by the need for such practice right from the beginning, as even in the schools with the longest training cycle the time available for teaching SI is short and must not be wasted.

Therefore, in the initial SI training phase the primary objectives should be to ensure that students are spared a traumatic first experience in the booth and that they are made aware of the correct approach right from the start. Once these goals have been achieved, 
students are sufficiently capable of monitoring their own performance to be able to practice between classes without acquiring bad habits.

\section{CRITICAL REVIEW OF PROCEDURES MOST COMMONLY USED}

Different procedures have been suggested to facilitate initial training in SI, but none of them is entirely satisfactory as a means of achieving the two aforementioned goals.

\section{a. Introductory preparation}

Since SI is a complex task, most teachers see to it that all the prerequisites for successful performance are actually met when students have their first try.

Students are familiarized with the equipment and the correct positioning of the headset and are introduced to the basics of SI (time lag, communication, etc.). Generally students start SI by working from their active foreign language (B language) into their mother tongue (A language). This reduces problems arising from any language deficiencies they may have. For their first attempt at SI, they will generally be given an impromptu speech on a non-technical subject with which they are familiar.

However, while these precautions are a good idea in themselves, they only represent preliminaries of training and not the training itself.

\section{b. Shadowing}

The shadowing technique is apparently still employed in some schools although most teachers now agree that it is useless and even counter-productive.

Indeed, instead of focusing students' attention on the cognitive content of an utterance shadowing makes them concentrate on the way it is worded, and thus prepares them not to interpret but to transcode it. Moreover, since it is perfectly possible to shadow a speaker without even attempting to understand what he is trying to get at, shadowing may indeed lead students to commit the worst possible methodological error in SI: mindless parroting1.

\section{c. Counting backwards}

This exercise consists in having students count backwards while listening to a speech in the A or B language and then having them summarize the speech to make sure they understood what they heard. The purpose is to convince them that they are able to perform two different tasks at the same time.

Although this exercise was designed as a way to make SI seem less daunting, I think that it instead makes the process appear to be more of a feat than it actually is, because SI in fact does not, at least as I see it, involve performing two different tasks at the same time.

In my view, the process involved in SI bears a close resemblance to the process involved in common speech. Indeed, when we speak off the cuff, we are simultaneously thinking about what we are going to say next, while expressing our previous thought and monitoring our output. (Slips of the tongue sometimes bear witness to this fact.) Yet we do not have the impression of performing different tasks at the same time, because all these mental operations are closely related and interdependent. When interpreting under optimal conditions (i.e. when working from a perfectly understood source language into our mother tongue on a completely familiar subject presented by a competent native speaker), we are doing practically the same thing as someone who is speaking in a single language, except that our train of thought is directed not by ourselves but by the speaker and we receive the input through our ears.

Therefore, it is mainly the ears that have to perform a dual task: the task of listening to the incoming message in one language and that of monitoring one's own output in 
another. But while this dual task poses problems that have to be addressed it is nevertheless not as difficult as it would be to perform two completely unrelated mental tasks at the same time. An exercise that is meant to be introductory, but in fact introduces the student to something other than the task to be executed, would seem somewhat pointless.

\section{d. Paraphrasing}

Paraphrasing is a useful introductory exercise because it is a good simulation of SI while being easier to perform. Consequently it is a good way to help students build selfconfidence and get used to working in the booth.

However, since paraphrasing is only a preliminary exercise, it may help achieve the first goal (a non-traumatic start), but it does not go far towards achieving the second (creating awareness of the proper approach to SI right from the beginning).

\section{CONSECUTIVE INTERPRETATION USED AS "TRAINING WHEELS"}

In my experience, the fastest and safest way to achieve both the above-mentioned goals at once is to make use of the consecutive technique which the students have already mastered.

\section{Rationale}

The rationale of this approach is of course the widely recognized fact that SI is merely a contraction of the consecutive technique with the different phases overlapping instead of following one another. Indeed it is for this reason that consecutive is normally taught before SI. It would therefore seem natural to use the technique of $\mathrm{CI}$ as an aid in teaching SI.

\section{Method}

In practical terms this means that during the initial stage of the training process, a long section of the speech to be interpreted in the booth (6 to 7 minutes) is first done in consecutive. It is only after this preliminary exercise and the discussion of any problems that may have cropped up, that students are asked to interpret the same section of the speech in the booth. A small segment of the speech that has not already been done in consecutive is added on.

Obviously students first receive introductory preparation as under (a) above. In addition, the topic is always announced one week in advance to allow students to prepare it by reading up on it in their target language.

During the exercise speeches are not read out, so the wording of the speech segment interpreted in consecutive may not be exactly the same when the speech is presented a second time for interpretation in simultaneous. This does not matter as long as the content remains unchanged.

\section{Purpose}

The purpose of the whole procedure is to get around the various problems of teaching SI set out at the beginning of the paper:

The SI-process cannot be broken down:

While the SI-process itself cannot be broken down in real time into more manageable tasks, it is possible to stage a kind of "dress rehearsal" (CI) prior to the actual performance (SI).

Students must fend for themselves:

In the booth students are told to interpret the presentation a second time with the help of their notes and while listening to the speaker, whose presentation is providing them with 
the necessary cues like a prompter. As long as students are following these instructions it is unlikely that they will go astray. By thus preprogramming the process it is possible to compensate for not being able, as one is in CI, to lead them through it step by step.

\section{Risk of transcoding:}

A segment of the speech which has not been interpreted in consecutive is added to the one that has. This makes students aware of the change in their approach when, as is invariably the case, they lose the thread of the speaker's argument, start to cling to the words rather than interpret the content, and falter. At this point the exercise is discontinued. Students are thus in a position to understand what made them change their approach and how this change affected their output.

\section{Advantages}

One big advantage of this method is that the student's self-confidence is bolstered by this first experience in the booth. Once the student is off to a good start and feels comfortable with the subject, it often happens, even on his first try, that he will manage to take a fairly long segment of speech not previously interpreted in consecutive in his stride before he falters and has to stop. The smooth start eliminates a good deal of the nervousness and tenseness that can lead to verbal tics that are subsequently very hard to get rid of.

Because they have been shown the right way to go about simultaneous, and because they have had first-hand experience with the right approach as well as with the wrong one, students can start practicing on their own right away. To be on the safe side, for the first week of practice they are asked to interpret only those parts of a speech in SI that they have previously done in CI. They are also asked to monitor their own performance by regularly tape-recording themselves. This advantage is of particular interest to extensive training programs where students have to do a lot of unsupervised work between classes.

A further advantage of the procedure is that it keeps students from parroting. Since the subject is a familiar one to start with and since they have explored it even further in their preliminary CI they are conditioned to focus, in their SI, on the two main activities involved in interpretation, i.e. cognitive analysis and re-expression. When their performance is good they are aware that this is because they were well prepared, and this in turn makes it far less likely that they will ever underestimate the importance of carefully preparing a subject by gaining an actual understanding of the substance involved and mastering the specific jargon in the target language, as opposed to simply looking up technical terms in a dictionary.

Finally, the procedure can be applied with a great deal of flexibility. The preliminary CI can be phased out fairly quickly or very gradually, depending on the pace at which students are progressing. At the start of phase-out, students are asked to do a consecutive but not to take their notes into the booth with them. Then, bit by bit, those parts of the speech done first in consecutive are shortened. By the time students are half-way through their training course they should be able to do without the preliminary consecutive altogether, although it can be reintroduced when necessary (e.g. when a student is having a bad day or difficulty with a particular subject or speaker). Before it is dropped altogether it can be compressed to a sort of "warm-up": the speaker will be asked, instead of repeating the entire part of the speech that has been done in consecutive, to simply summarize it briefly before continuing his speech for interpretation in simultaneous only.

This flexibility is especially welcome when teaching students with unusual language combinations who have to train in SI from their A into their B language. The "training wheel" procedure can be reintroduced at this point to help them counteract their tendency (natural when working into a B language) to translate literally: and since linguistic problems 
are by definition persistent in a $\mathbf{B}$ language, the procedure must be phased out more slowly. (Often, in fact, it should not be discontinued at all unless it has to be for lack of time.)

\section{DISCUSSION}

Does this procedure make it possible to train simultaneous interpreters better and faster? Though it is tempting to say that it does, such a statement would be very hard to prove. At an interpreting school such as, for example, the ESIT where students have many different teachers, each of whom has his or her own teaching method, there is no way to measure the efficacy of any one method.

Furthermore, even if a group of students has only one teacher - which can happen - the group is generally too small to be of any statistical significance. In one such class which I taught, there were three students, two of whom reached professional level in SI on the parts of a moderately technical speech not previously done in consecutive after two months of extensive training ( $11 / 2$ hours of class per week). But obviously no general conclusions can be drawn on the basis of such a small number of students.

A further complicating factor in this case is that it became apparent that the two students who succeeded met all the linguistic requirements for SI into their A language, while the third did not. Indeed, it sometimes happens that slight language deficiencies which go unnoticed in consecutive are revealed in simultaneous since the latter makes much higher demands on both the source and the target language. One of the reasons for this may be the fact that the ears have to perform a dual task, as mentioned above: splitting auditory capacity between the speaker and one's own output reduces listening efficiency, while hearing two different languages at the same time increases the risk of linguistic interference, thus adversely affecting both perception in the source language and expression in the target language.

This negative effect on the target language is particularly striking when SI is done into a $\mathrm{B}$ language, but it is also noticeable in the mother tongue. Thus problems of re-expression which make their first appearance in SI and at first glance might seem to be due to faulty method (transcoding) may in fact turn out under closer scrutiny to be due to a linguistic problem in the target language.

The same holds true for slight deficiencies in the source language. If comprehension of the source language is not completely effortless the reduced efficiency of the listening operation in SI may cause problems. This is sometimes the case with students' passive $\mathrm{C}$ languages, which can be inadequate for the specific listening conditions in SI and for anticipation. Obviously, the students' ability to anticipate where the speaker is going depends partly on their understanding the language and partly on their knowledge of the subject and ability to use this knowledge. Familiarity with the subject can offset language deficiencies to some extent in CI, but much less so in SI. Here again, problems in SI may be due not to a lack of method but to linguistic deficiencies gone unnoticed in consecutive.

Language problems of this type are best diagnosed very early on. Diagnosis should, ideally, take place before the start of training. A language proficiency test of the same high sensitivity as SI would therefore be very welcome.

\section{CONCLUSION}

To conclude, it seems to me that even though it has not been possible so far to measure the effectiveness of the approach to teaching SI set out above, it is nevertheless a method worth trying, if only because it makes the crucial initial SI training phase seem, to both teacher and students, as safe and reassuring as learning to ride a bicycle with training wheels. 


\section{Note}

1. Shadowing is an excellent way to improve a B language precisely because it draws attention to every single word of an utterance, especially structure words which normally do not even register when heard and are therefore particularly difficult to get right. But shadowing, and indeed B language improvement techniques in general, are the exact opposite of the approach needed to learn interpreting.

\section{REFERENCES}

HENDERSON, J. (1982): "Some Psychological Aspects of Simultaneous Interpreting", Fremdsprachen, 1, pp. 21-27

HARRIS, B. (1992): “Teaching Interpreting: A Canadian Experience”, Dollerup, C. \& Loddegard, A. (Eds), Teaching Translation and Interpreting, Amsterdam/Philadelphia, John Benjamins Publishing Company, pp. 259-268.

HERBERT, J. (1952): Manuel de l'interprète, Genève, Georg.

KAINZ, F. (1965): Psychologie der Sprache, Stuttgart, Encke.

KEISER, W. (1978): "Selection and Training of Simultaneous Interpreters", Gerver, D. \& Sinaiko, H. W. (Eds), Language Interpretation and Communication, New York, Plenum Press.

KURZ, I. (1992): "Shadowing Exercises in Interpreter Training", Dollerup, C. \& Loddegard, A. (Eds), Teaching Translation and Interpreting, Amsterdam / Philadelphia, John Benjamins Publishing Company, pp. 245-250.

LONGLEY, P. (1989): "The Use of Aptitude Testing in the Selection of Students of Conference Interpretation Training", Gran, L. \& Dodds, J. (Eds), The Theoretical and Practical Aspects of Teaching Conference Interpretation, Udine, Campanotto Editore, pp. 105-108.

MOSER, B. (1983): "Testing Interpreting Aptitude", Wilss, W. \& Thome, G. (Eds), Die Theorie des Übersetzens und ihr Aufschlußwert für die Übersetzungs- und Dolmetschdidaktik, Tübingen, Gunter Narr Verlag, pp. 318-325.

SELESKOVITCH, D. \& M. LEDERER (1989): Pédagogie raisonnée de l' interprétation, Paris, Didier Érudition.

STROLZ, B. (1992): Argumente für einen kontextuellen Top-down-Ansatz der Verarbeitung und Produktion von Sprache, Unpublished Doktorarbeit, Wien, Universität Wien.

DÉJEAN LE FEAL, K. (1981): "L'enseignement des méthodes d'interprétation", Delisle, J. (Ed.), L'enseignement de l' interprétation et de la traduction, Cahiers de traductologie, $\mathrm{n}^{\circ} 4$, Ottawa, Éditions de l'Université d'Ottawa, pp. 380-403.

DÉJEAN LE FEAL, K. (1990a): "Some Thoughts on the Evaluation of Simultaneous Interpretation", Bowen, D. \& M. Bowen (Eds), Interpreting - Yesterday, Today and Tomorrow, American Translators Association Series, Volume IV, Binghamton, State University, pp. 154-160.

DÉJEAN LE FÉAL, K. (1990b): “La formation méthodologique d'interprètes de langues «exotiques»", Lederer, M. (Ed.), Études traductologiques, Paris, Minard, pp. 201-213.

DÉJEAN LE FÉAL, K. (1992): "Comment un interprète de conférence perfectionne ses langues actives et passives", Les Nouveaux Cahiers d'Allemand, $\mathrm{n}^{\circ}$ 1, pp. 7-19. 